\title{
"Does performance persistence exist in mutual and pension funds? Evidence from Turkey"
}

\begin{tabular}{|c|c|c|}
\hline AUTHORS & \multicolumn{2}{|l|}{ Tayfun Ozkan (10) } \\
\hline ARTICLE INFO & \multicolumn{2}{|c|}{$\begin{array}{l}\text { Tayfun Ozkan and Hakki Ozturk (2021). Does performance persistence exist in } \\
\text { mutual and pension funds? Evidence from Turkey. Investment Management and } \\
\text { Financial Innovations, 18(4), 326-339. doi:10.21511/imfi.18(4).2021.27 }\end{array}$} \\
\hline DOI & \multicolumn{2}{|c|}{ http://dx.doi.org/10.21511/imfi.18(4).2021.27 } \\
\hline RELEASED ON & \multicolumn{2}{|l|}{ Tuesday, 07 December 2021} \\
\hline RECEIVED ON & \multicolumn{2}{|l|}{ Wednesday, 22 September 2021} \\
\hline ACCEPTED ON & \multicolumn{2}{|l|}{ Thursday, 25 November 2021} \\
\hline LICENSE & \multicolumn{2}{|c|}{$\begin{array}{l}\text { This work is licensed under a Creative Commons Attribution } 4.0 \text { International } \\
\text { License }\end{array}$} \\
\hline JOURNAL & \multicolumn{2}{|c|}{ "Investment Management and Financial Innovations" } \\
\hline ISSN PRINT & \multicolumn{2}{|l|}{$1810-4967$} \\
\hline ISSN ONLINE & \multicolumn{2}{|l|}{$1812-9358$} \\
\hline PUBLISHER & \multicolumn{2}{|c|}{ LLC "Consulting Publishing Company "Business Perspectives" } \\
\hline FOUNDER & \multicolumn{2}{|c|}{ LLC "Consulting Publishing Company "Business Perspectives" } \\
\hline$\sigma^{0}$ & 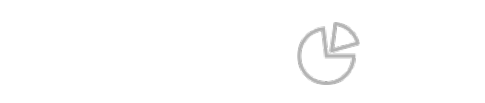 & 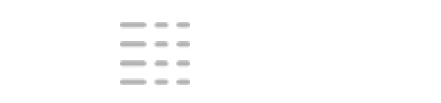 \\
\hline NUMBER OF REFERENCES & NUMBER OF FIGURES & NUMBER OF TABLES \\
\hline 21 & 2 & 13 \\
\hline
\end{tabular}

(c) The author(s) 2022. This publication is an open access article. 


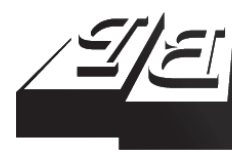

BUSINESS PERSPECTIVES

()

LLC "CPC "Business Perspectives" Hryhorii Skovoroda lane, 10, Sumy, 40022, Ukraine www.businessperspectives.org
Received on: $22^{\text {nd }}$ of September, 2021 Accepted on: $25^{\text {th }}$ of November, 2021 Published on: $7^{\text {th }}$ of December, 2021

(C) Tayfun Ozkan, Hakki Ozturk, 2021

Tayfun Ozkan, Dr., Graduate School, Bahcesehir University, Turkey.

Hakki Ozturk, Assoc. Prof., Faculty of Economics, Administrative and Social Sciences, International Finance Department, Bahcesehir University, Turkey. (Corresponding author)

Tayfun Ozkan (Turkey), Hakki Ozturk (Turkey)

\title{
DOES PERFORMANCE PERSISTENCE EXIST IN MUTUAL AND PENSION FUNDS? EVIDENCE FROM TURKEY
}

\begin{abstract}
The objective of this study is to investigate the performance persistence of Turkish mutual and pension funds. 310 mutual and 259 pension funds were analyzed between the period of 2010-2019 in order to determine if there is an evidence of performance persistence. In this study, a persistence rate is developed, and the skill ratio is used to crosscheck the results of the persistence rate. Furthermore, six different risk-adjusted return measures, such as Sharpe, Treynor, Information, Jensen's alpha, Sortino, and Omega ratios are calculated to analyze whether funds also exhibit superior risk-adjusted returns. The results indicate that only $2 \%$ of funds demonstrate persistence above $50 \%$, and 15 out of 20 fund categories do not have any funds that show persistence in 10 years. Most of the persistent funds have positive skill ratios, and it is observed that the persistence rate is effective. However, it cannot be stated that there is performance persistence in the Turkish fund management industry, since performance persistence is not evident for various fund types, so investors do not need to invest in the best funds of the previous year. Additionally, the empirical results associated with risk-adjusted performance analysis indicate that persistent funds also do not generally yield higher risk-adjusted returns. The lack of persistence in funds' performance is a significant result for investors in their investment decisions, for fund managers in their human resource policies and bonus schemes, and for regulators in their policy decisions.
\end{abstract}

\section{Keywords}

JEL Classification

\section{INTRODUCTION}

Performance persistence is a research topic in the fund performance literature where researchers examine whether funds can record continued positive performance (i.e., whether successful funds continue to be successful in the following period). The outcomes of persistence research are crucial for investors because if performance persistence exists, investors may opt for funds that are persistent in successful performance and may earn better returns in the subsequent period.

The aim of this study is to identify whether performance persistence exists in Turkish mutual and pension funds in the period of 20102019. The results are important and play a critical role for all investors, fund managers and regulators.

Savings and capital accumulation are insufficient in Turkey to grow its economy. Hence, it requires foreign capital, which renders it susceptible to economic crises. Another policy to fuel growth is to commingle small savings via fund management. This policy can work only if the fund management industry generates acceptable, i.e., above-market returns in a sustainable manner. This empirical study explores whether the industry generates such returns and investigates the performance persistence in mutual and pension funds during 10 years. Between the period 2010 and 2019, the Turkish fund management industry, includ- 
ing both mutual and pension funds (which represent 90 percent of the industry as of 2019), is covered and 310 mutual and 259 pension funds' return performances are analyzed.

The asset management industry emerges and grows with capital accumulation. The more available capital for financial investment, the more the asset management services is required.

Therefore, larger mutual funds are observed in developed countries compared to developing ones in terms of the AuM (Assets under Management)/GDP ratio. Asset management is a relatively newly flourishing industry in Turkey. The regulatory developments helped growing the asset management industry both in terms of number of asset managers (from 30s to more than 50) and AuM (from 50 billion TL to 351 billion TL) between 2010-2020/09 ${ }^{1}$. Since asset management is an emerging industry in Turkey, it is important to analyze whether Turkish funds have performance persistence and generate excess risk-adjusted returns.

\section{LITERATURE REVIEW}

Many studies have focused on the persistence performance of mutual funds, and these studies have concluded with varying results. Findings generally show mixed results depending on different time periods and different samples used.

Hendricks et al. (1993) explore the short-term persistence of equity funds in the USA by using quarterly data during the period 1974-1988. According to results, they find short-term persistence of mutual funds. Successful funds of the recent year continue to perform well in the short run (one to eight quarters). They claim that the funds that show positive performance have hot hands. They also report that the investment strategies based on hot hands can increase returns by six percent per year. If some fund managers have hot hands, they have an ability to produce persistent risk-adjusted excess returns. These fund managers that outperformed in previous periods tend to outperform in future periods.

Goetzmann and Ibbotson (1994) analyze $728 \mathrm{mu}-$ tual funds in the USA during a 13-year period from 1976 to 1988 to determine whether the past performances of mutual funds continue in the future. They conclude that past returns and relative rankings of mutual funds explain future returns and rankings. In this study, a repeat-winner pattern is also indicated over one and two-year intervals.

Brown and Goetzmann (1995) study the performance persistence of mutual funds in the USA between 1976-1988. They claim that seven years of the total sample show significant persistence. According to findings, performance persistence of mutual funds also exists on the relative risk-adjusted basis.

Wermers (1997) examines the performance persistence of US mutual funds between 1975-1994. He claims that top performing funds of the recent year continue to perform well for the next year, however there are four exceptional years. This study indicates that the persistence of mutual funds is significant. This result is related with the momentum effect, since after the momentum effect is controlled for one year, the performance persistence of mutual funds seems to vanish.

A study conducted by Grinblatt and Titman (1992) covers 279 mutual funds from 1974 to 1984 . They investigate whether past performance of mutual funds is related with future. They report that performance persistence is evident. They also conclude that the ability of fund managers is important in performance persistence.

Elton et al. (1996) analyze performance persistence of 188 US mutual funds from 1977 to 1993. They observe that performance persistence is valid in one-year period, and they also detect past performances of mutual funds explain future performance over a three-year period when risk-adjusted returns are considered.

On the contrary, there are also some early studies that do not report fund performance persis-

1 For more information please refer to TCMA (2020). 
tence. Jensen (1968) used Jensen's alpha to calculate risk-adjusted abnormal returns for 115 openend mutual funds and analyzed the performance of these funds between the period 1945-1964. The findings show that there is little evidence that individual funds perform better than predicted by chance.

Carhart (1997) added a momentum factor to the Fama-French three-factor model and used the data of diversified equity funds in the USA from January 1962 to December 1993. He finds that high-yield funds last year had higher-than-average expected returns next year, but not in years thereafter, so the results in Carhart's research do not support the existence of skilled or informed mutual fund portfolio managers.

Collinet and Firer (2003) analyze the performance persistence of South African Equity Funds between 1980 and 1999. They suggested the regression of percentile ranks as a means of testing performance persistence. The results show that there is a positive but weak relationship between past and future performance rankings. According to regression analysis, where the period is 6-12 months, past performance has very little explanatory power in explaining future performance, and in some periods, there was no relationship between rankings of two consecutive periods. However, in some periods, significant short-term persistence was observable.

Filip (2011) also utilizes percentile ranks regression to analyze the performance persistence in Hungary mutual funds between 2000 and 2009. The findings indicate that there is evidence of short-term performance persistence.

Keswani and Stolin (2006) examine performance persistence of UK mutual funds covering data from 1991 to 2001. They report that performance persistence is higher among sectors in which the concentration of assets under management is higher.

Abdel-Kader and Qing (2007) investigate risk-adjusted performance of 30 Hong Kong mutual funds by employing Jensen's alpha, Treynor ratio and three-factor models. They use weekly re- turns between the period 1995-2005. The results indicate that Hong Kong mutual funds underperform the market according to Jensen's alpha and Treynor ratio.

Casarin et al. (2008) analyze the performance persistence of Italian equity funds. They do not support long-run persistence on risk-adjusted returns of Italian equity funds.

Huang and Mahieu (2012) examine the performance persistence of Dutch pension funds between the period 1998-2006. The results show that there is no persistence in pension fund performance over time.

Urbański et al. (2016) investigate long-run persistence of 161 Polish funds between the period 2000-2012. They find five-year persistence of Sharpe ratio for safe funds; however, they do not report any evidence for five-year persistence in hybrid and stock funds.

Rao et al. (2016) study the performance persistence of Chinese equity funds covering data for the period 2004 to 2014. The results show that Chinese equity funds beat their benchmarks, however, there is no evidence of persistence in the performance of Chinese funds. They claim that last year's well performing funds do not continue to perform well next year.

Another study by Rao et al. (2020) attempts to evaluate performance persistence of equity mutual funds in China. The data covers 714 mutual funds from 2004 to 2015 . According to the results of this study, there is no significant evidence of performance persistence. The authors claim that the future performance of funds is not related with their past performance, and they report that the winner funds do not continue to be winners in the years to come.

Deb (2019) uses a sample of 263 equity mutual funds in India between 2000 and 2014 to investigate the performance persistence. The results of this study indicate that performance persistence exists over a 12-month horizon, however this performance persistence for the short term disappears for longer periods of 24 months and 36 months. 


\section{DATA AND METHODOLOGY}

The literature suggests that performance persistence can be measured by ranking funds and predicting alpha (by controlling Fama and French (1993) factors and Carhart (1997) model in general. In this study, the funds are examined in terms of their rankings in their peer group (i.e., fund category) at first. One may claim that a fund having performance persistence should remain in the top rankings in its peer group. Considering this sound claim, percentile ranking is used, which shows relative position of a fund's performance (Collinet \& Firer, 2003; Filip, 2011), to examine whether funds remain in the top quartile consistently. Therefore, "persistence rate" is developed, which is the number of weeks when the fund is in the top quartile over the total number of weeks during the life of the fund in the analysis. Persistence rate is calculated as follows.

It is considered that a fund with persistent performance should be in the top quartile (i.e., the first 25 percent) at least half (50 percent) of the total period.

The second approach to persistence is examining the skill ratio ${ }^{3}$ of asset managers by using rolling excess returns (Blais, 2018). Skill ratio is measured as follows.

This skill ratio is quite like information ratio, yet a rolling return for 52-week period is used instead of weekly data. Albeit positive skill ratios can be plausible, it is considered that funds having ratios over 1.0 as successful in performance persistence.
Skill ratio is included in the study as well because skill ratio measures the performance in terms of creating excess return, whereas rankings do not consider the level of excess returns.

The risk-adjusted performance measures, which are Sharpe, Treynor, Information, Jensen's alpha, Sortino, and Omega ratios of the identified persistent funds, are also calculated and analyzed to see if the funds generate excess risk-adjusted returns.

To calculate a specific fund's return performance within its category, first it is needed to define the fund's category. Therefore, 8 mutual and 12 pension fund categories are identified. Table 1 depicts the fund categories, the number of funds in each category, and the total size (i.e., assets under management $t^{4}$ ) of the category per year for the analyzed 10 -year period.

Over the analyzed 10-year period, some funds ceased to exist, and some funds joined the market naturally, and hence the total of the number of funds in each year in Table 1 does not represent the total of different funds taken into consideration in each category. A total of 310 different mutual funds grouped in 8 fund categories and a total of 259 different pension funds grouped in 12 fund categories are covered within the analysis in the 10-year period between $2010-2019$.

The fund returns data are calculated based on the daily fund prices obtained from Takas İstanbul ${ }^{5}$, the settlement and custody bank. Takas İstanbul is the central settlement and clearing institution for investment and pension funds, and hence stores

Persistence Rate $=\frac{\text { Number of Weeks in the Top Quartile }}{\text { Total Number of Weeks }}$.

Skill Ratio $=\frac{\text { Average Rolling 52-Week Excess Return }}{\text { Average Rolling 52-Week Excess Return Standard Deviation }}$.

\footnotetext{
Total Number of Weeks can maximum be 520 if the relevant fund has been in existence for the whole analyzed 10 years.

For more information please refer to Blais (2018).

Assets under management $(\mathrm{AuM})$ is the annual average in million Turkish Liras.

Takas İstanbul is short for İstanbul Settlement and Custody Bank Inc., part of Borsa İstanbul Group. Takas İstanbul provides clearing, settlement, and custody services within the framework of capital market and related exchange regulations. Therefore, Takas İstanbul is the original source of the data. This data was also used in a chapter of Tayfun Ozkan's PhD dissertation under the supervision of Assoc. Prof. Hakki Ozturk. This study is based on the chapter mentioned above.
} 
Source: Authors' categorization based on the CMB (Capital Markets Board of Turkey) data.

\begin{tabular}{|c|c|c|c|c|c|c|c|c|c|c|c|c|c|c|c|c|c|c|c|c|c|}
\hline & \multirow{2}{*}{ AuM in million TL } & \multicolumn{2}{|c|}{2010} & \multicolumn{2}{|c|}{2011} & \multicolumn{2}{|c|}{2012} & \multicolumn{2}{|c|}{2013} & \multicolumn{2}{|c|}{2014} & \multicolumn{2}{|c|}{2015} & \multicolumn{2}{|c|}{2016} & \multicolumn{2}{|c|}{2017} & \multicolumn{2}{|c|}{2018} & \multicolumn{2}{|c|}{2019} \\
\hline & & $\#$ & AuM & $\#$ & AuM & $\#$ & AuM & $\#$ & AuM & \# & AuM & $\#$ & AuM & \# & AuM & $\#$ & AuM & \# & AuM & $\#$ & AuM \\
\hline \multirow{9}{*}{ 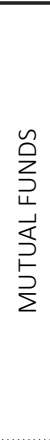 } & Gold Fund & 9 & 276 & 11 & 859 & 13 & 955 & 12 & 589 & 12 & 395 & 12 & 287 & 12 & 280 & 12 & 385 & 12 & 497 & 14 & 940 \\
\hline & Fixed Income Fund & 44 & 2,298 & 47 & 1,688 & 60 & 1,651 & 62 & 2,582 & 63 & 2,992 & 66 & 3,995 & 62 & 4,232 & 58 & 4,269 & 53 & 3,863 & 36 & 3,536 \\
\hline & Equity Fund & 51 & 604 & 53 & 948 & 61 & 803 & 62 & 1,157 & 66 & 1,069 & 71 & 1,163 & 70 & 1,212 & 69 & 1,546 & 69 & 1,731 & 53 & 1,565 \\
\hline & Multi Asset Fund & 15 & 305 & 14 & 297 & 13 & 336 & 13 & 411 & 13 & 409 & 12 & 435 & 11 & 438 & 10 & 495 & 10 & 522 & 6 & 504 \\
\hline & Lease Certificates Fund & 4 & 78 & 7 & 165 & 7 & 142 & 10 & 143 & 11 & 77 & 19 & 87 & 24 & 131 & 25 & 207 & 28 & 450 & 14 & 527 \\
\hline & ST Fixed Income Fund & 6 & 74 & 15 & 1,658 & 27 & 7,980 & 29 & 10,127 & 29 & 12,393 & 29 & 13,952 & 26 & 16,094 & 26 & 17,667 & 28 & 16,513 & 28 & 15,298 \\
\hline & ST Lease Certificates Fund & 0 & 0 & 0 & 0 & 0 & 0 & 0 & 0 & 0 & 0 & 0 & 0 & 0 & 0 & 4 & 169 & 5 & 485 & 8 & 2,554 \\
\hline & Money Market Fund & 50 & 22,844 & 44 & 21,434 & 39 & 14,554 & 41 & 13,401 & 39 & 11,815 & 36 & 13,527 & 29 & 12,495 & 27 & 13,344 & 27 & 14,206 & 24 & 31,841 \\
\hline & Total mutual funds & 179 & 26,479 & 191 & 27,048 & 220 & 26,421 & 229 & 28,410 & 233 & 29,150 & 245 & 33,446 & 234 & 34,882 & 231 & 38,082 & 232 & 38,268 & 183 & 56,766 \\
\hline \multirow{13}{*}{ 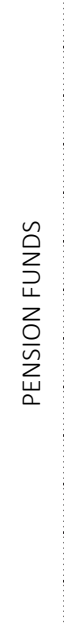 } & Gold Fund & 0 & 0 & 0 & 0 & 0 & 0 & 12 & 35 & 13 & 193 & 12 & 440 & 12 & 932 & 14 & 2,412 & 14 & 5,392 & 16 & 11,519 \\
\hline & Initiation Fund & 0 & 0 & 0 & 0 & 0 & 0 & 0 & 0 & 0 & 0 & 0 & 0 & 8 & 0 & 14 & 273 & 14 & 472 & 14 & 427 \\
\hline & Initiation Participation Fund & 0 & 0 & 0 & 0 & 0 & 0 & 0 & 0 & 0 & 0 & 0 & 0 & 10 & 0 & 16 & 448 & 16 & 762 & 17 & 655 \\
\hline & Fixed Income Fund & 14 & 4,086 & 15 & 4,789 & 17 & 7,117 & 17 & 8,522 & 17 & 9,454 & 17 & 10,903 & 17 & 11,457 & 17 & 11,821 & 23 & 14,986 & 22 & 11,624 \\
\hline & Government Contr. Fund & 0 & 0 & 0 & 0 & 0 & 0 & 18 & 603 & 18 & 1,923 & 18 & 3,746 & 18 & 5,956 & 18 & 8,344 & 17 & 9,755 & 17 & 12,589 \\
\hline & Equity Fund & 20 & 596 & 26 & 954 & 27 & 1,188 & 28 & 1,784 & 29 & 2,204 & 29 & 2,772 & 29 & 3,480 & 29 & 4,335 & 31 & 4,963 & 33 & 4,667 \\
\hline & Government Bonds Fund & 12 & 1,241 & 13 & 1,473 & 9 & 877 & 10 & 1,280 & 10 & 1,505 & 10 & 1,799 & 10 & 2,066 & 10 & 2,286 & 11 & 2,852 & 10 & 3,100 \\
\hline & FC Denom. Gov. Bonds Fund & 20 & 425 & 22 & 541 & 22 & 708 & 22 & 795 & 22 & 1,220 & 22 & 2,393 & 22 & 3,775 & 22 & 5,981 & 22 & 8,845 & 24 & 12,680 \\
\hline & Gov. Contr. Participation Fund & 0 & 0 & 0 & 0 & 0 & 0 & 7 & 18 & 8 & 80 & 8 & 177 & 10 & 293 & 13 & 397 & 13 & 548 & 15 & 998 \\
\hline & Standard Participation Fund & 1 & 0 & 2 & 12 & 3 & 56 & 6 & 127 & 8 & 275 & 8 & 549 & 8 & 904 & 25 & 1,252 & 26 & 2,788 & 28 & 5,217 \\
\hline & Money Market Fund & 17 & 1,173 & 19 & 1,186 & 21 & 1,577 & 23 & 1,748 & 23 & 2,970 & 23 & 4,037 & 23 & 5,846 & 23 & 7,050 & 22 & 8,362 & 18 & 10,668 \\
\hline & Standard Fund & 5 & 351 & 7 & 460 & 8 & 672 & 17 & 1,099 & 17 & 1,750 & 17 & 2,859 & 17 & 3,873 & 31 & 5,015 & 31 & 6,136 & 29 & 5,997 \\
\hline & Total pension funds & 89 & 7,872 & 104 & 9,416 & 107 & 12,196 & 160 & 16,013 & 165 & 21,573 & 164 & 29,675 & 184 & 38,581 & 232 & 49,614 & 240 & 65,861 & 243 & 80,143 \\
\hline
\end{tabular}

Note: ST: Short-term, FC Denom.: Foreign Currency Denominated, Gov. Contr.: Government Contribution. 
all the fund prices, i.e., returns data. The daily fund prices of all funds between January 2, 2010 to December 31, 2019 are obtained. It is preferred to use weekly returns as an optimum compared to:

- daily returns that would contain much noise, and

- monthly returns that may miss some information.

Weekly returns would dampen the noise and contain most relevant information required for our performance analysis. Weekly returns of the funds are calculated as follows:

$$
\text { Fund Return }=r_{i}=\frac{P_{t}-P_{t-7}}{P_{t-7}},
$$

where - weekly returns of the fund $i, P_{t}$ - price of the fund at the $t$ day, $P_{t-7}$ - price of the fund 7 days before the $t$ day.

A week is defined as a calendar week, i.e., Monday to Monday.

Each week, funds are ranked based on their weekly return performance within their categories. Then the total number of weeks when a specific fund is in the first quartile is counted for each fund for the analyzed 10-year period. Finally, the persistence rate is calculated as per the formula stated above.

The persistence analysis in this sense is solely based on return ranking of the funds within each category, i.e., the analysis so far does not consider whether there has been a positive and superior (to any benchmark) return performance. Hence, it is further analyzed whether the persistent funds also deliver superior risk-adjusted return performances.

Six different risk-adjusted return measures are used in three different group of metrics, namely:

1) absolute risk-adjusted return measures that evaluate portfolio (i.e., fund category) returns without any reference to a benchmark but to the risk-free rate,
2) relative risk-adjusted return measures that evaluate portfolio (i.e., fund category) returns in reference to a benchmark, and

3) measures based on downside risk and higher moments where risk is perceived only as the downside risk rather than the total volatility around the mean and additional moments of the return distribution are also taken into consideration such as kurtosis and skewness.

Sharpe and Treynor ratios are used as absolute risk-adjusted return measures, and the two-year government bond yield is chosen as the risk-free rate (which is a market consensus) in Turkey ${ }^{6}$.

Sharpe and Treynor ratios are calculated as follows:

$$
\begin{aligned}
& \text { Sharpe ratio }=\frac{\overline{R_{p}}-\overline{R_{f}}}{\sigma\left(R_{p}-R_{f}\right)}, \\
& \text { Treynor ratio }=\frac{\overline{R_{p}}-\overline{R_{f}}}{\beta_{p}},
\end{aligned}
$$

where

$\overline{R_{p}}=$ Average portfolio (fund category) returns for the period $=\left(\sum_{i}^{n} R_{p}\right) / n$,

$\overline{R_{f}}=$ Average risk-free rate of return for the peri$\mathrm{od}=\left(\sum_{i}^{n} R_{f}\right) / n$.

$\sigma\left(R_{p}-R_{f}\right)=$

$=$ St. deviation of excess returns $=$

$=\sqrt{\frac{1}{n-1} \sum_{i}^{n}\left(\left(R_{p}^{i}-R_{f}^{i}\right)-\frac{\sum_{i}^{n}\left(R_{p}^{i}-R_{f}^{i}\right)}{n}\right)^{2}}$

$\beta_{p}=\frac{\sum_{i=1}^{n}\left(R_{p}^{i}-\overline{R_{p}}\right) \cdot\left(R_{B}^{i}-\overline{R_{B}}\right)}{\sum_{i=1}^{n}\left(R_{B}^{i}-\overline{R_{B}}\right)^{2}}$.

Information ratio and Jensen's alpha are also used as relative risk-adjusted performance measures, and a category-specific benchmark for each fund category is defined as shown in Table 2.

6 Turkish Institutional Investment Managers' Association publishes an annual performance report on pension funds in Turkey since 2016 and they use the two-year government bond yield as the risk-free rate of return. http://www.tkyd.org.tr/assets/raporlar 


$$
\text { Information ratio }=\frac{\overline{R_{p}}-\overline{R_{B}}}{\sigma\left(R_{p}-R_{B}\right)},
$$

(8) Sortino ratio $=\frac{\overline{R_{p}}-\overline{R_{B}}}{D R}$,

$$
\begin{aligned}
& \text { Jensen's alpha }=\alpha_{p}= \\
& =\left[\overline{R_{p}}-\left\{\overline{R_{f}}+\beta_{p} \cdot\left(\overline{R_{B}}-\overline{R_{f}}\right)\right\}\right],
\end{aligned}
$$

where

$\overline{R_{B}}=$ Average benchmark return for the period $=\left(\sum_{i}^{n} R_{B}\right) / n$,

$\sigma\left(R_{p}-R_{B}\right)=$

$=$ St. deviation of excess returns $=$

$$
=\sqrt{\frac{1}{n-1} \sum_{i}^{n}\left(\left(R_{p}^{i}-R_{B}^{i}\right)-\frac{\sum_{i}^{n}\left(R_{p}^{i}-R_{B}^{i}\right)}{n}\right)^{2}} .
$$

In the third group of metrics, Sortino and Omega ratios are calculated as follows:

$$
\text { Omega ratio }=\frac{\sum_{i=1}^{n}\left(R_{p}^{i}-R_{B}^{i}\right) \cdot f(x)}{\sum_{i=1}^{n}\left(R_{B}^{i}-R_{p}^{i}\right) \cdot f(y)},
$$

where

$$
\begin{aligned}
& D R=\text { Downside Risk }=\sqrt{\frac{1}{n} \sum_{i=1}^{n}\left(R_{p}-R_{B}\right)^{2} \cdot f(t),} \\
& f(t)=1 \text { if } R_{p}<R_{B}, \\
& f(t)=0 \text { if } R_{p} \geq R_{B}, \\
& f(x)=1 \text { if } R_{p} \geq R_{B}, f(x)=0 \text { if } R_{p}<R_{B}, \\
& f(y)=1 \text { if } R_{B} \geq R_{p}, f(y)=0 \text { if } R_{B}<R_{p} .
\end{aligned}
$$

\begin{tabular}{|c|c|c|}
\hline & Fund categories & Category benchmarks \\
\hline \multirow{8}{*}{ 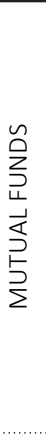 } & Gold Fund & BIST-KYD Gold Price Index (calculated over averages) \\
\hline & Fixed Income Fund & $\begin{array}{l}\% 50 \text { TDTUMT1: BIST-KYD Government All T1 + } \% 30 \text { OSABTT1: BIST-KYD Private Sector Fixed T1 + } \\
+\% 20 \text { ODEGST1 BIST-KYD Private Sector Floating T1 }\end{array}$ \\
\hline & Equity Fund & BIST All Total Return Index \\
\hline & Multi Asset Fund & $\begin{array}{l}\text { \%10 TD91G: BIST-KYD Government } 91 \text { Days + \%25 BIST All Total Return Index + } \\
+\% 65 \text { TDTUMT1: BIST-KYD Government All T1 }\end{array}$ \\
\hline & Participation Fund & $\begin{array}{l}\% 50 \text { KDEVLT1: BIST-KYD Government Lease Certificates T1 +\%50 KOZELT1: BIST-KYD Private } \\
\text { Sector Lease Certificates T1 }\end{array}$ \\
\hline & Short-term Fixed Income Fund & TD91G: BIST-KYD Government 91 GUN \\
\hline & $\begin{array}{l}\text { Short-term Lease Certificates } \\
\text { Fund }\end{array}$ & $\begin{array}{l}\% 50 \text { KDEVLT1: BIST-KYD Government Lease Certificates T1 + \%50 KOZELT1: BIST-KYD Private } \\
\text { Sector Lease Certificates T1 }\end{array}$ \\
\hline & Money Market Fund & TD91G: BIST-KYD Government 91 GUN \\
\hline \multirow{12}{*}{ 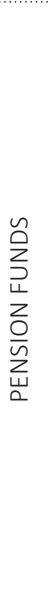 } & Gold Fund & BIST-KYD Gold Price Index (calculated over averages) \\
\hline & Initiation Fund & BIST-KYD 1 Month Time Deposit Index \\
\hline & Initiation Participation Fund & BIST-KYD 1 Month Time Participation Account Index \\
\hline & Fixed Income Fund & $\begin{array}{l}\% 50 \text { TDTUMT1: BIST-KYD Government All T1 + } \% 30 \text { OSABTT1: BIST-KYD Private Sector Fixed T1 + } \\
+\% 20 \text { ODEGST1 BIST-KYD Private Sector Floating T1 }\end{array}$ \\
\hline & Government Contribution Fund & BIST-KYD Government All T1 \\
\hline & Equity Fund & BIST All Total Return Index \\
\hline & Government Bonds Fund & BIST-KYD Government All T1 \\
\hline & $\begin{array}{l}\text { Foreign Currency Denominated } \\
\text { Government Bonds Fund }\end{array}$ & $\begin{array}{l}\text { \%50 EBUSD: BIST-KYD Government EUROBOND USD + \%50 EBEUR BIST-KYD Government } \\
\text { EUROBOND EUR }\end{array}$ \\
\hline & $\begin{array}{l}\text { Government Contribution } \\
\text { Participation Fund }\end{array}$ & KDEVLT1: BIST-KYD Government Lease Certifcates T1 \\
\hline & Standard Participation Fund & $\begin{array}{l}\% 50 \text { KDEVLT1 BIST-KYD Government Lease Certifcates T1 + \%20 BIST-KYD Gold Price Index + } \\
\text { + \%30 BIST-KYD } 1 \text { Month Time Participation Account Index }\end{array}$ \\
\hline & Money Market Fund & TD91G: BIST-KYD Government 91 Days \\
\hline & Standard Fund & $\begin{array}{l}\% 50 \text { TDTUMT1: BIST-KYD Government All T1 + \%30 BIST-KYD } 1 \text { Month Time Deposit Index + } \\
+\% 10 \text { BIST All Total Return Index + } \% 10 \text { BIST-KYD Gold Price Index }\end{array}$ \\
\hline
\end{tabular}

A total of more than 1 million data in terms of daily prices of 569 funds and daily values of 12 different benchmarks are analyzed, and six different risk-adjusted performance measures are calculated in this study.

Table 2. Defined category benchmarks 


\section{RESULTS}

\subsection{Mutual funds}

Table 3 groups the number of funds based on persistence rate intervals. Accordingly, 54 (17.4\%) of 310 mutual funds have been ranked in the first quartile for 10 percent or less of their lives (number of weeks of their existence) within the analyzed 10 -year period. Another 91 mutual funds have been ranked in the first quartile for more than 10 percent and less than 20 percent of their lives within the analyzed 10-year period, and so on, as shown in Table 3.

Table 3. Summary statistics of persistence rates in mutual funds

\begin{tabular}{l|c|c} 
& & \multicolumn{2}{c}{ Source: Authors' calculations. } \\
\hline Persistence rate & \# of funds & \% of funds \\
\hline $0-10 \%$ & 54 & $17.4 \%$ \\
\hline $10 \%-20 \%$ & 91 & $29.4 \%$ \\
\hline $20 \%-30 \%$ & 76 & $24.5 \%$ \\
\hline $30 \%-40 \%$ & 51 & $16.5 \%$ \\
\hline $40 \%-50 \%$ & 28 & $9.0 \%$ \\
\hline $\mathbf{5 0 \% - 6 0 \%}$ & $\mathbf{6}$ & $\mathbf{1 . 9 \%}$ \\
\hline $60 \%-70 \%$ & 0 & $0.0 \%$ \\
\hline $\mathbf{7 0 \% - 8 0 \%}$ & $\mathbf{3}$ & $\mathbf{1 . 0 \%}$ \\
\hline $80 \%-90 \%$ & 0 & $0.0 \%$ \\
\hline $\mathbf{9 0 \% - 1 0 0 \%}$ & $\mathbf{1}$ & $\mathbf{0 . 3 \%}$ \\
\hline Total & $\mathbf{3 1 0}$ & $\mathbf{1 0 0 . 0 \%}$ \\
\hline
\end{tabular}

It is observed that only 10 mutual funds have been ranked in the first quartile for more than 50 percent of their lives (the total of 6, 3, and 1 with 50\%$60 \%, 70 \%-80 \%$, and $90 \%-100 \%$ persistence rates, respectively). In other words, only 3.2 percent of mutual funds have been persistent in their return performances in the analyzed 10 -year period.

Figure 1 is the histogram of Table 2 and illustrates that most mutual funds could not achieve persistent return performance within the analyzed 10 -year period.

Table 4 exhibits the distribution of the number of funds in each percentile per mutual fund category to examine whether there is a performance persistence at the mutual fund category level. The findings indicate that only fixed income related mutual funds (namely fixed income, short term fixed income, and money market fund categories) can record persistence. None of the funds in the equity, precious metals, participation, short-term participation, or balanced funds categories are able to record a persistent return performance.

The following ten funds ${ }^{7}$ in Table 5 are identified as being persistent in their return performances (sorted by the persistence rate; the most persistent being at the top).

As stated earlier in the Data and Methodology section, Sharpe, Treynor, Information, Jensen's Alpha and Omega ratios are calculated whether the persistent funds also deliver superior risk-adjusted return performances. Table 6 indicates that IBV, IST, TZL, IPL, TPE, and KUB are able to deliver positive (in case of Omega, Sortino and Information) results as per almost all performance measures (TPE and KUB have negative Treynor ratios, and IST has zero Sharpe and Treynor Ratio though).

Source: Authors' calculations.

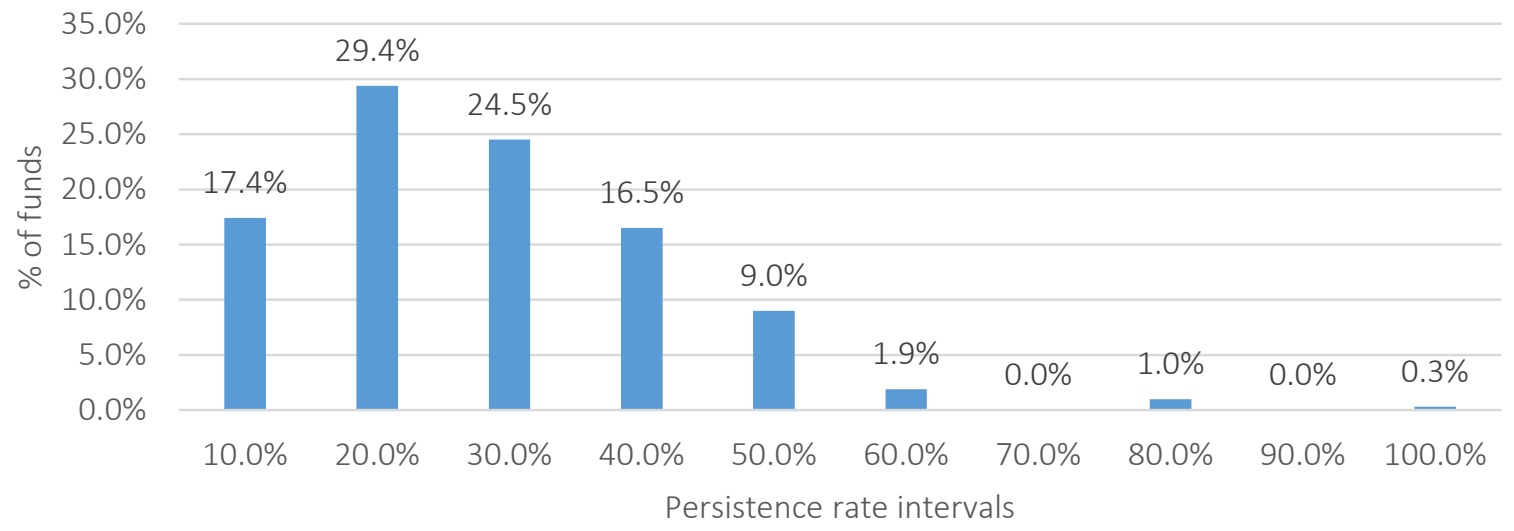

Figure 1. Histogram of persistence rate in mutual funds

\footnotetext{
7 Fund names and other details pertaining to the single funds can be accessed on www.tefas.gov.tr by using the three-letter fund codes.
} 
Table 4. Persistence rate of funds in each mutual fund category

\begin{tabular}{|c|c|c|c|c|c|c|c|c|c|c|c|c|c|c|c|c|}
\hline \multicolumn{17}{|c|}{ Source: Authors' calculations. } \\
\hline \multirow{2}{*}{$\begin{array}{c}\begin{array}{c}\text { Persistence } \\
\text { rate } \\
\text { intervals }\end{array} \\
0-10 \%\end{array}$} & \multicolumn{2}{|c|}{$\begin{array}{c}\text { Precious } \\
\text { metal funds }\end{array}$} & \multicolumn{2}{|c|}{$\begin{array}{l}\text { Fixed } \\
\text { income } \\
\text { funds }\end{array}$} & \multicolumn{2}{|c|}{ Equity funds } & \multicolumn{2}{|c|}{$\begin{array}{l}\text { Balanced } \\
\text { funds }\end{array}$} & \multicolumn{2}{|c|}{$\begin{array}{c}\text { Participation } \\
\text { funds }\end{array}$} & \multicolumn{2}{|c|}{$\begin{array}{c}\text { ST fixed } \\
\text { income } \\
\text { funds }\end{array}$} & \multicolumn{2}{|c|}{$\begin{array}{c}\text { ST } \\
\text { participation } \\
\text { funds }\end{array}$} & \multicolumn{2}{|c|}{$\begin{array}{c}\text { Money } \\
\text { market } \\
\text { funds }\end{array}$} \\
\hline & 1 & $7 \%$ & 16 & $18 \%$ & 8 & $9 \%$ & 1 & $10 \%$ & 7 & $25 \%$ & 9 & $29 \%$ & 3 & $50 \%$ & 9 & $22 \%$ \\
\hline $10 \%-20 \%$ & 8 & $53 \%$ & 21 & $23 \%$ & 24 & $27 \%$ & 4 & $40 \%$ & 10 & $36 \%$ & 7 & $23 \%$ & 2 & $33 \%$ & 15 & $37 \%$ \\
\hline $20 \%-30 \%$ & 4 & $27 \%$ & 22 & $24 \%$ & 33 & $37 \%$ & 3 & $30 \%$ & 3 & $11 \%$ & 6 & $19 \%$ & 0 & $0 \%$ & 5 & $12 \%$ \\
\hline $30 \%-40 \%$ & 2 & $13 \%$ & 14 & $16 \%$ & 18 & $20 \%$ & 2 & $20 \%$ & 5 & $18 \%$ & 5 & $16 \%$ & 1 & $17 \%$ & 4 & $10 \%$ \\
\hline $40 \%-50 \%$ & 0 & $0 \%$ & 15 & $17 \%$ & 6 & $7 \%$ & 0 & $0 \%$ & 3 & $11 \%$ & 1 & $3 \%$ & 0 & $0 \%$ & 3 & $7 \%$ \\
\hline $50 \%-60 \%$ & 0 & $0 \%$ & 2 & $2 \%$ & 0 & $0 \%$ & 0 & $0 \%$ & 0 & $0 \%$ & 0 & $0 \%$ & 0 & $0 \%$ & 4 & $10 \%$ \\
\hline $60 \%-70 \%$ & 0 & $0 \%$ & 0 & $0 \%$ & 0 & $0 \%$ & 0 & $0 \%$ & 0 & $0 \%$ & 0 & $0 \%$ & 0 & $0 \%$ & 0 & $0 \%$ \\
\hline $70 \%-80 \%$ & 0 & $0 \%$ & 0 & $0 \%$ & 0 & $0 \%$ & 0 & $0 \%$ & 0 & $0 \%$ & 2 & $6 \%$ & 0 & $0 \%$ & 1 & $2 \%$ \\
\hline $80 \%-90 \%$ & 0 & $0 \%$ & 0 & $0 \%$ & 0 & $0 \%$ & 0 & $0 \%$ & 0 & $0 \%$ & 0 & $0 \%$ & 0 & $0 \%$ & 0 & $0 \%$ \\
\hline $90 \%-100 \%$ & 0 & $0 \%$ & 0 & $0 \%$ & 0 & $0 \%$ & 0 & $0 \%$ & 0 & $0 \%$ & 1 & $3 \%$ & 0 & $0 \%$ & 0 & $0 \%$ \\
\hline Total & 15 & & 90 & & 89 & & 10 & & 28 & & 31 & & 6 & & 41 & \\
\hline
\end{tabular}

Table 5. Mutual funds persistent in performance

Source: Authors' calculations.

\begin{tabular}{|c|c|c|}
\hline Fund code & Fund category & Persistence rate \\
\hline IBV & Short-term Fixed Income Mutual Funds & $94.0 \%$ \\
\hline IST & Short-term Fixed Income Mutual Funds & $76.5 \%$ \\
\hline GBL & Money Market Mutual Funds & $73.5 \%$ \\
\hline KRB & Short-term Fixed Income Mutual Funds & $70.1 \%$ \\
\hline ANL & Money Market Mutual Funds & $57.1 \%$ \\
\hline SMB & Money Market Mutual Funds & $54.1 \%$ \\
\hline TZL & Money Market Mutual Funds & $52.3 \%$ \\
\hline IPL & Money Market Mutual Funds & $50.8 \%$ \\
\hline TPE & Fixed Income Mutual Funds & $50.4 \%$ \\
\hline KUB & Fixed Income Mutual Funds & $50.4 \%$ \\
\hline
\end{tabular}

Table 6. Performance measures of persistent mutual funds

Source: Authors' calculations.

\begin{tabular}{|c|c|c|c|c|c|c|c|}
\hline Fund code & $\begin{array}{c}\text { Persistence } \\
\text { rate }\end{array}$ & $\begin{array}{c}\text { Sharpe } \\
\text { ratio }\end{array}$ & Treynor ratio & $\begin{array}{c}\text { Information } \\
\text { ratio }\end{array}$ & Jensen's alpha & $\begin{array}{l}\text { Sortino } \\
\text { ratio }\end{array}$ & Omega ratio \\
\hline IBV & $94.0 \%$ & 0.29 & 0.003 & 0.24 & 0.0002 & 0.55 & 2.14 \\
\hline IST & $76.5 \%$ & 0.00 & 0.000 & 0.01 & 0.0000 & 0.02 & 1.06 \\
\hline GBL & $73.5 \%$ & -0.04 & 0.000 & 0.00 & 0.0000 & -0.01 & 0.99 \\
\hline KRB & $70.1 \%$ & -0.06 & -0.002 & -0.11 & -0.0002 & -0.19 & 0.74 \\
\hline ANL & $57.1 \%$ & -0.04 & 0.000 & -0.09 & -0.0001 & -0.12 & 0.78 \\
\hline SMB & $54.1 \%$ & -0.06 & -0.002 & -0.53 & -0.0004 & -0.76 & 0.25 \\
\hline TZL & $52.3 \%$ & 0.15 & 0.000 & 0.05 & 0.0001 & 0.10 & 1.18 \\
\hline IPL & $50.8 \%$ & 0.07 & 0.000 & 0.06 & 0.0000 & 0.11 & 1.19 \\
\hline TPE & $50.4 \%$ & 0.13 & -0.002 & 0.11 & 0.0053 & 0.23 & 1.38 \\
\hline KUB & $50.4 \%$ & 0.10 & -0.001 & 0.09 & 0.0049 & 0.16 & 1.30 \\
\hline
\end{tabular}

The findings in Table 6 do not suggest that mutual funds with persistent performance would be expected to deliver superior risk-adjusted performance as well. Negative (and below 1 in case of Omega) risk-adjusted performance ratios in four out of the ten funds with above 50 percent persistence rates indicate that persistent performance does not necessarily mean superior risk-adjusted results.
Other than rankings, "skill ratio" is examined for mutual funds. To compare the results of the skill ratio with the results of the ranking method, skill ratios of funds classified as persistent in the ranking method are examined. As Table 7 indicates, not all persistent funds have positive skill ratios (i.e., positive active return). 
Table 7. Skill ratios of persistent mutual funds

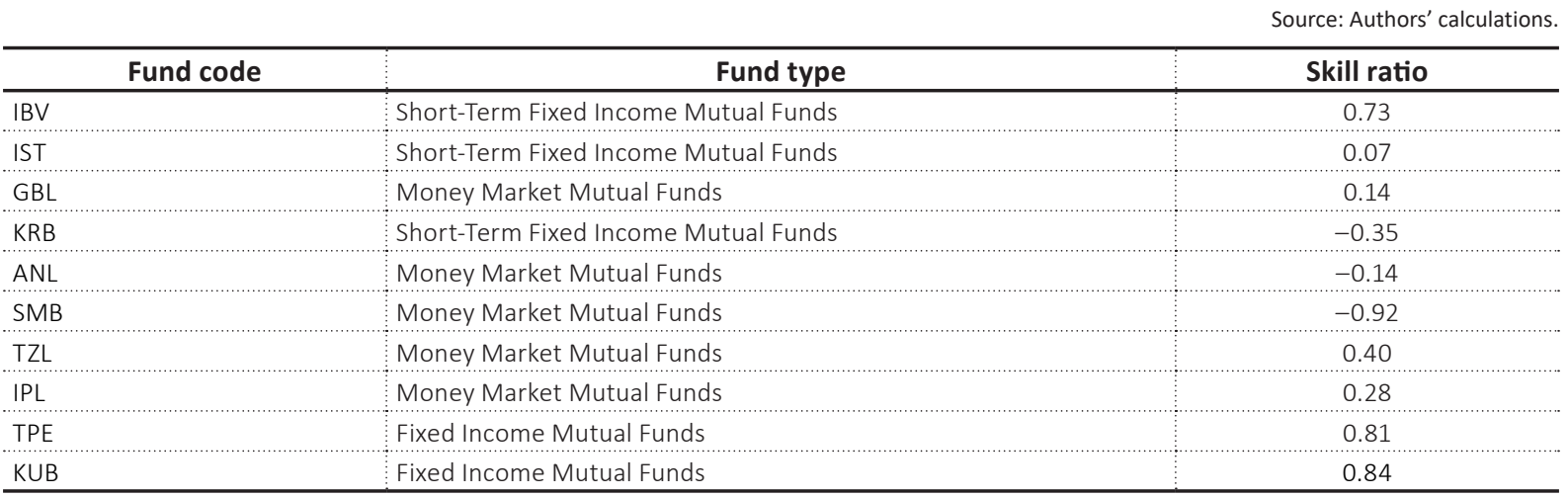

Table 8. Summary statistics of persistence rates in pension funds

Source: Authors' calculations.

\begin{tabular}{|c|c|c|}
\hline Persistence rate & \# of funds & $\%$ of funds \\
\hline $0-10 \%$ & 25 & $9.7 \%$ \\
\hline $10 \%-20 \%$ & 87 & $33.6 \%$ \\
\hline $20 \%-30 \%$ & 86 & $33.2 \%$ \\
\hline $30 \%-40 \%$ & 35 & $13.5 \%$ \\
\hline $40 \%-50 \%$ & 24 & $9.3 \%$ \\
\hline $50 \%-60 \%$ & 2 & $0.8 \%$ \\
\hline $60 \%-70 \%$ & 0 & $0.0 \%$ \\
\hline $70 \%-80 \%$ & 0 & $0.0 \%$ \\
\hline $80 \%-90 \%$ & 0 & $0.0 \%$ \\
\hline $90 \%-100 \%$ & 0 & $0.0 \%$ \\
\hline Total & 259 & $100.0 \%$ \\
\hline
\end{tabular}

\subsection{Pension funds}

The results for pension funds are like mutual funds as expected because both fund types are managed by the same asset managers in Turkey. However, the persistence performance is weaker in pension funds. Only two funds out of 259 funds remained in the first quartile over 50 percent of the total time horizon. The number and percentage of total pension funds per quartile are listed in Table 8 and illustrated in Figure 2. The distribution of these funds per fund categories is also listed in Table 9.

Table 12 exhibits the distribution of the number of funds in each persistence rate interval per pension fund category.

Among KEY and VGL, KEY is a successful fund in terms of performance metrics as well. Its Sharpe and Information ratios are positive (Table 10).

Source: Authors' calculations.

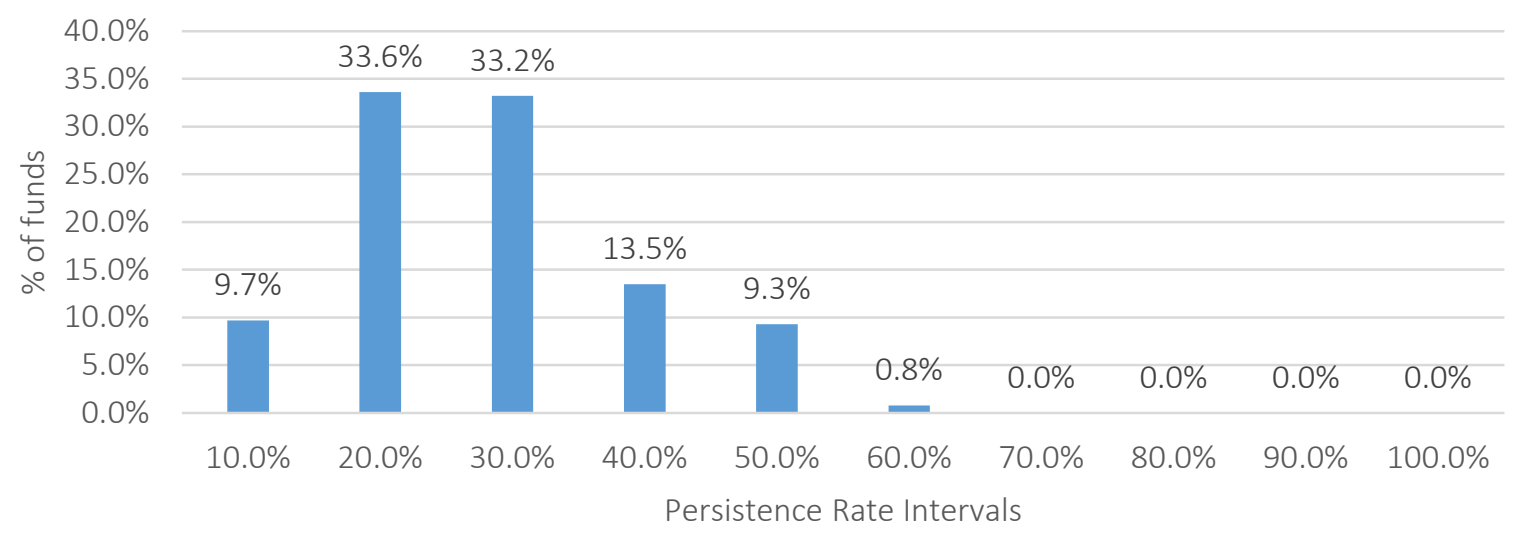

Figure 2. Histogram of persistence rate in pension funds 
Table 9. Pension funds persistent in performance

Source: Authors' calculations.

\begin{tabular}{|c|c|c|}
\hline Fund code & Fund category & Persistence rate \\
\hline KEY & Initial Participation Pension Fund & $59.5 \%$ \\
\hline VGL & Money Market Pension Fund & $51.3 \%$ \\
\hline
\end{tabular}

Table 10. Performance measures of persistent pension funds

Source: Authors' calculations.

\begin{tabular}{|c|c|c|c|c|c|c|c|}
\hline Fund code & $\begin{array}{c}\text { Persistence } \\
\text { rate }\end{array}$ & $\begin{array}{c}\text { Sharpe } \\
\text { ratio }\end{array}$ & $\begin{array}{c}\text { Information } \\
\text { ratio }\end{array}$ & $\begin{array}{c}\text { Sortino } \\
\text { ratio }\end{array}$ & Treynor ratio & Omega ratio & Jensen's alpha \\
\hline KEY & $59.5 \%$ & 0.1278 & 1.1418 & 11.1159 & 0.00017 & 31.9382 & $4.30564 \mathrm{E}-05$ \\
\hline VGL & $51.3 \%$ & -0.1532 & -0.0199 & -0.0301 & -0.0002 & 0.9412 & $-4.9742 E-05$ \\
\hline
\end{tabular}

Table 11. Skill ratios of persistent pension funds

Source: Authors' calculations.

\begin{tabular}{l|c|c}
\hline \multicolumn{1}{c}{ Fund code } & Fund type & Skill ratio \\
\hline KEY & Initial Participation Pension Fund & 0.528 \\
\hline VGL & Money Market Pension Fund & 0.016 \\
\hline
\end{tabular}

KEY's skill ratio is also more powerful than VGL (Table 11).

Tables 8-12 show that there is no performance persistence in the analyzed 10-year period for pension funds and that only one of the exceptional two pension funds with just above $50 \%$ persistence rates can deliver superior risk-adjusted performance.

Table 13 summarizes persistence rates, skill ratios of funds and calculation of six different risk-adjusted performance measures of the persistent funds as described in Section 2.

According to the findings in Table 13, only 12 of 569 funds analyzed have exhibited persistence above $50 \%$, and 8 of them exhibited less than $60 \%$ persistence. In other words, only four funds (all of which are short-term mutual funds) have ranked in the first quartile within their categories in more than $70 \%$ of the 520 weeks analyzed between 2010-2019. 15 out of 20 fund categories (mutual and pension funds combined) do not have any funds that have exhibited at least $50 \%$ performance persistence in 10 years. Hence, it cannot be stated that there is performance persistence in the Turkish fund management industry. Since performance persistence is not evident for various fund types, investors do not need to invest in the best funds of the previous year.
When "skill ratios" of funds are examined, which are classified as persistent in the ranking method to crosscheck the effectiveness of the persistence rate, Table 13 indicates that 9 of the 12 persistent funds have positive skill ratios (i.e., positive active return). It can be argued that persistence rate is effective.

Table 13 also shows six different risk-adjusted performance measures of the persistent funds. Sharpe and Treynor ratios measure the absolute risk-adjusted performance, i.e., whether the funds yield higher risk-adjusted returns than the risk-free rate. Information ratio and Jensen's alpha measure the relative performance, i.e., whether the funds yield higher risk-adjusted returns than the fund category benchmark. Finally, Sortino and Omega ratios measure again the relative performance, but with respect to negative volatility only, i.e., taking into consideration the downside risk and the probability of gains vs losses. It is identified that 7 of 12 funds (namely IBV, IST, TZL, IPL, TPE, KUB, and KEY) exhibit at least one successful risk-adjusted performance result. While 7 funds have successful Sortino, Omega, and Information ratios, 6 funds have positive Sharpe ratios, 4 funds have positive Jensen's alpha ratios, and only 2 funds have positive Treynor ratios. In other words, 5 of the 12 performance persistent funds (42 percent) do not have any successful risk-adjusted performance result. This result states that persistent funds do not also generally gain higher risk-adjusted returns. 
Table 12. Persistence rate of funds in each pension fund category

Source: Authors' calculations.

\begin{tabular}{|c|c|c|c|c|c|c|c|c|c|c|c|c|c|c|c|c|c|c|c|c|c|c|c|c|}
\hline \multirow{2}{*}{$\begin{array}{c}\begin{array}{c}\text { Persistence } \\
\text { rate } \\
\text { intervals }\end{array} \\
0-10 \%\end{array}$} & \multicolumn{2}{|c|}{ Gold funds } & \multicolumn{2}{|c|}{$\begin{array}{l}\text { Initiation } \\
\text { funds }\end{array}$} & \multicolumn{2}{|c|}{$\begin{array}{c}\text { Initiation } \\
\text { participation } \\
\text { funds }\end{array}$} & \multicolumn{2}{|c|}{$\begin{array}{l}\text { Fixed income } \\
\text { funds }\end{array}$} & \multicolumn{2}{|c|}{$\begin{array}{c}\text { Government } \\
\text { contribution } \\
\text { funds }\end{array}$} & \multicolumn{2}{|c|}{ Equity funds } & \multicolumn{2}{|c|}{$\begin{array}{l}\text { Government } \\
\text { fixed income } \\
\text { funds }\end{array}$} & \multicolumn{2}{|c|}{\begin{tabular}{c|} 
FC \\
Government \\
fixed income \\
funds \\
\end{tabular}} & \multicolumn{2}{|c|}{$\begin{array}{c}\text { Participation } \\
\text { contribution } \\
\text { funds }\end{array}$} & \multicolumn{2}{|c|}{$\begin{array}{c}\text { Standard } \\
\text { participation } \\
\text { funds }\end{array}$} & \multicolumn{2}{|c|}{$\begin{array}{l}\text { Standard } \\
\text { funds }\end{array}$} & \multicolumn{2}{|c|}{$\begin{array}{c}\text { Money } \\
\text { market funds }\end{array}$} \\
\hline & 0 & $0 \%$ & 0 & $0 \%$ & 5 & $31 \%$ & 5 & $18 \%$ & 0 & $0 \%$ & 0 & $0 \%$ & 1 & $7 \%$ & 4 & $17 \%$ & 1 & $8 \%$ & 3 & $9 \%$ & 1 & $3 \%$ & 5 & $22 \%$ \\
\hline $10 \%-20 \%$ & 7 & $50 \%$ & 7 & $50 \%$ & 3 & $19 \%$ & 9 & $32 \%$ & 10 & $56 \%$ & 13 & $42 \%$ & 2 & $14 \%$ & 5 & $21 \%$ & 2 & $17 \%$ & 14 & $40 \%$ & 7 & $23 \%$ & 8 & $35 \%$ \\
\hline $20 \%-30 \%$ & 5 & $36 \%$ & 5 & $36 \%$ & 2 & $13 \%$ & 7 & $25 \%$ & 5 & $28 \%$ & 9 & $29 \%$ & 7 & $50 \%$ & 6 & $25 \%$ & 7 & $58 \%$ & 15 & $43 \%$ & 15 & $50 \%$ & 3 & $13 \%$ \\
\hline $30 \%-40 \%$ & 2 & $14 \%$ & 2 & $14 \%$ & 4 & $25 \%$ & 3 & $11 \%$ & 2 & $11 \%$ & 4 & $13 \%$ & 2 & $14 \%$ & 4 & $17 \%$ & 1 & $8 \%$ & 1 & $3 \%$ & 7 & $23 \%$ & 3 & $13 \%$ \\
\hline $40 \%-50 \%$ & 0 & $0 \%$ & 0 & $0 \%$ & 1 & $6 \%$ & 4 & $14 \%$ & 1 & $6 \%$ & 5 & $16 \%$ & 2 & $14 \%$ & 5 & $21 \%$ & 1 & $8 \%$ & 2 & $6 \%$ & 0 & $0 \%$ & 3 & $13 \%$ \\
\hline $50 \%-60 \%$ & 0 & $0 \%$ & 0 & $0 \%$ & 1 & $6 \%$ & 0 & $0 \%$ & 0 & $0 \%$ & 0 & $0 \%$ & 0 & $0 \%$ & 0 & $0 \%$ & 0 & $0 \%$ & 0 & $0 \%$ & 0 & $0 \%$ & 1 & $4 \%$ \\
\hline $60 \%-70 \%$ & 0 & $0 \%$ & 0 & $0 \%$ & 0 & $0 \%$ & 0 & $0 \%$ & 0 & $0 \%$ & 0 & $0 \%$ & 0 & $0 \%$ & 0 & $0 \%$ & 0 & $0 \%$ & 0 & $0 \%$ & 0 & $0 \%$ & 0 & $0 \%$ \\
\hline $70 \%-80 \%$ & 0 & $0 \%$ & 0 & $0 \%$ & 0 & $0 \%$ & 0 & $0 \%$ & 0 & $0 \%$ & 0 & $0 \%$ & 0 & $0 \%$ & 0 & $0 \%$ & 0 & $0 \%$ & 0 & $0 \%$ & 0 & $0 \%$ & 0 & $0 \%$ \\
\hline $80 \%-90 \%$ & 0 & $0 \%$ & 0 & $0 \%$ & 0 & $0 \%$ & 0 & $0 \%$ & 0 & $0 \%$ & 0 & $0 \%$ & 0 & $0 \%$ & 0 & $0 \%$ & 0 & $0 \%$ & 0 & $0 \%$ & 0 & $0 \%$ & 0 & $0 \%$ \\
\hline $90 \%-100 \%$ & 0 & $0 \%$ & 0 & $0 \%$ & 0 & $0 \%$ & 0 & $0 \%$ & 0 & $0 \%$ & 0 & $0 \%$ & 0 & $0 \%$ & 0 & $0 \%$ & 0 & $0 \%$ & 0 & $0 \%$ & 0 & $0 \%$ & 0 & $0 \%$ \\
\hline Total & 14 & $100 \%$ & 14 & $100 \%$ & 16 & $100 \%$ & 28 & $100 \%$ & 18 & $100 \%$ & 31 & $100 \%$ & 14 & $100 \%$ & 24 & $100 \%$ & 12 & $100 \%$ & 35 & $100 \%$ & 30 & $100 \%$ & 23 & $100 \%$ \\
\hline
\end{tabular}

Table 13. Summary of persistence analysis

Source: Authors' calculations.

\begin{tabular}{|c|c|c|c|c|c|c|c|c|c|c|}
\hline $\begin{array}{l}\text { Fund } \\
\text { code }\end{array}$ & $\begin{array}{l}\text { Mutual/ } \\
\text { Pension }\end{array}$ & Fund Type & Persistence rate & Sharpe & Treynor & Information & $\begin{array}{c}\text { Jensen's } \\
\text { alpha }\end{array}$ & Sortino & Omega & Skill ratio \\
\hline IBV & Mutual & ST Fixed Income & $94.0 \%$ & 0.2900 & 0.0030 & 0.2400 & 0.0002 & 0.5500 & 2.1400 & 0.730 \\
\hline IST & Mutual & ST Fixed Income & $76.5 \%$ & 0.0000 & 0.0000 & 0.0100 & 0.0000 & 0.0200 & 1.0600 & 0.070 \\
\hline GBL & Mutual & Money Market & $73.5 \%$ & -0.0400 & 0.0000 & 0.0000 & 0.0000 & -0.0100 & 0.9900 & 0.140 \\
\hline KRB & Mutual & ST Fixed Income & $70.1 \%$ & -0.6000 & -0.0020 & -0.1100 & -0.0002 & -0.1900 & 0.7400 & -0.350 \\
\hline ANL & Mutual & Money Market & $57.1 \%$ & -0.0400 & 0.0000 & -0.0900 & -0.0001 & -0.1200 & 0.7800 & -0.140 \\
\hline SMB & Mutual & Money Market & $54.1 \%$ & -0.6000 & -0.0020 & -0.5300 & -0.0004 & -0.7600 & 0.2500 & -0.920 \\
\hline TZL & Mutual & Money Market & $52.3 \%$ & 0.1500 & 0.0000 & 0.0500 & 0.0001 & 0.1000 & 1.1800 & 0.400 \\
\hline $\mathrm{IPL}$ & Mutual & Money Market & $50.8 \%$ & 0.0700 & 0.0000 & 0.0600 & 0.0000 & 0.1100 & 1.1900 & 0.280 \\
\hline TPE & Mutual & Fixed Income & $50.4 \%$ & 0.1300 & -0.0002 & 0.1100 & 0.0053 & 0.2300 & 1.3800 & 0.810 \\
\hline KUB & Mutual & Fixed Income & $50.4 \%$ & 0.1000 & -0.0001 & 0.0900 & 0.0049 & 0.1600 & 1.3000 & 0.840 \\
\hline KEY & Pension & Initial Participation & $59.5 \%$ & 0.1278 & 0.0020 & 1.1400 & 0.0000 & 11.1159 & 31.9382 & 0.528 \\
\hline VGL & Pension & Money Market & $51.3 \%$ & -0.1532 & -0.0002 & -0.0199 & 0.0000 & -0.0300 & 0.9412 & 0.016 \\
\hline
\end{tabular}


Although not directly relevant with the objective of this study, another observation vis-àvis Table 13 is that the Omega ratio is a better risk-adjusted performance measure in capturing persistence. Except for one of the funds ("SMB"), the Omega ratios of funds with high persistence ratios are either very close to or above 1, whereas other ratios may yield negative results. Researchers may further analyze specifically whether Omega ratio better captures persistent risk-adjusted performance than some other performance measures.

\section{CONCLUSION}

This paper explores performance persistence in mutual and pension funds in Turkey. Firstly, rankings of funds in their peer categories on a weekly basis for a 10-year period are examined. Secondly, "skill ratio" is used to crosscheck the effectiveness of the ranking method. The risk-adjusted performance measures such as Sharpe, Treynor, Information, Jensen's alpha, Sortino, and Omega ratios of the identified persistent funds are also calculated and analyzed to see if the funds generate excess risk-adjusted returns.

The overall results indicate that a small portion of mutual funds have been able to show performance persistence and that the outcome has been much weaker in pension funds. Hence, it cannot be concluded that there is performance persistence in the Turkish fund management industry as performance persistence is not evident for various fund types. When analyzed the six risk-adjusted performance ratios (Sharpe, Treynor, Information, Jensen's alpha, Sortino, and Omega), the results also indicate that persistent funds do not generally generate higher risk-adjusted returns.

The lack of persistence in funds' performance is a significant result for investors, fund managers, and regulators. Investors cannot rely on any significant fund that has been successful in the past to be successful in the future, and therefore the disclaimer that past performance is not a guarantee of future performance. Fund managers should be focused on continued successful performance rather than being a champion for once or twice within their categories. Bonus schemes may be structured to incentivize long-term continued success to enable fund managers create performance persistence. In Turkey, portfolio managers are licensed and personally tracked by the regulator. The regulator also keeps records of individual fund managers managing each fund. The regulator may keep track of the performances of individual portfolio managers and make that information available to whom it might be relevant to incentivize performance-based recruitment in the industry. This data may also allow academicians to perform further research on fund performances based on the educational backgrounds, experiences, and other characteristics of portfolio managers.

For future research recommendations, hedge funds can also be examined, because hedge funds are not restricted as mutual and pension funds; thus, the impact of asset allocation restrictions on fund performance can be measured.

\section{AUTHOR CONTRIBUTIONS}

Conceptualization: Tayfun Ozkan, Hakki Ozturk.

Data curation: Tayfun Ozkan.

Formal analysis: Tayfun Ozkan, Hakki Ozturk.

Investigation: Tayfun Ozkan.

Methodology: Tayfun Ozkan, Hakki Ozturk.

Resources: Tayfun Ozkan, Hakki Ozturk.

Software: Tayfun Ozkan, Hakki Ozturk.

Supervision: Hakki Ozturk.

Validation: Hakki Ozturk. 
Visualization: Tayfun Ozkan.

Writing - original draft: Tayfun Ozkan.

Writing - review \& editing: Hakki Ozturk.

\section{REFERENCES}

1. Abdel-Kader, M., \& Qing, K. Y. (2007). Risk-adjusted performance, selectivity, timing ability, and performance persistence of Hong Kong mutual funds. Journal of Asia-Pacific Business, 8(2), 25-58. https://doi.org/10.1300/ J098v08n02_03

2. Blais, D. (2018). Skill Ratio: A New Measure for the (Lack of) Persistence in Active Management. Retrieved from https://blogs.cfainstitute.org/investor/2018/03/26/ skill-ratio-a-new-metric-foractive-management/

3. Brown, S. J., \& Goetzmann, W. N. (1995). Performance persistence. The Journal of Finance, 50(2), 679-698. https://doi. org/10.1111/j.1540-6261.1995 tb04800.x

4. Carhart, M. M. (1997). On persistence in mutual fund performance. The Journal of Finance, 52(1), 57-82. https://doi. org/10.1111/j.1540-6261.1997. tb03808.x

5. Casarin, R., Pelizzon, L., \& Piva, A. (2008). Italian equity funds: efficiency and performance persistence. University Ca'Foscari of Venice.

6. Collinet, L., \& Firer, C. (2003). Characterising persistence of performance amongst South African general equity unit trusts. Omega, 31(6), 523-538. https://doi. org/10.1016/j.omega.2003.08.008

7. Deb, S. G. (2019). Persistence in performance of actively managed equity mutual funds: New Indian evidence. IIMB Management Review, 31(2), 145-156. https://doi. org/10.1016/j.iimb.2019.03.014

8. Elton, E. J., Gruber, M. J., \& Blake, C. R. (1996). The persistence of risk-adjusted mutual fund performance. Journal of Business, 69(2), 133-157. Retrieved from https:// papers.ssrn.com/sol3/papers. cfm?abstract_id $=6656$
9. Fama, E., \& French, K. (1993). Common Risk Factors in the Returns on Stocks and Bonds. Journal of Financial Economics, 33(1), 3-56. https://doi.org/10.1016/0304405X(93)90023-5

10. Filip, D. (2011). Performance persistence of equity funds in Hungary. Contemporary Economics, 5(1), 18-34. http://dx.doi. org/10.5709/ce.1897-9254.2

11. Goetzmann, W. N., \& Ibbotson, R. G. (1994). Do winners repeat? Journal of Portfolio Management, 20(2), 9-18.

12. Grinblatt, M., \& Titman, S. (1992). The persistence of mutual fund performance. The Journal of Finance, 47(5), 1977-1984. https:// doi.org/10.2307/2329005

13. Hendricks, D., Patel, J., \& Zeckhauser, R. (1993). Hot hands in mutual funds: Short-run persistence of relative performance, 1974-1988. The Journal of Finance, 48(1), 93-130. https://doi. org/10.2307/2328883

14. Huang, X., \& Mahieu, R. J. (2012). Performance persistence of Dutch pension funds. De Economist, 160(1), 17-34. https://doi. org/10.1007/s10645-011-9176-3

15. Jensen, M. C. (1968). The performance of mutual funds in the period 1945-1964. The Journal of Finance, 23(2), 389-416. https:// doi.org/10.1111/j.1540-6261.1968. tb00815.x

16. Keswani, A., \& Stolin, D. (2006). Mutual fund performance persistence and competition: A cross-sector analysis. Journal of Financial Research, 29(3), 349-366. https://doi.org/10.1111/j.14756803.2006.00182.x

17. Rao, Z. U. R., Tauni, M. Z., Ahsan, T., \& Umar, M. (2020). Do mutual funds have consistency in their performance? Portuguese
Economic Journal, 19(2), 139-153. https://doi.org/10.1007/s10258019-00163-2

18. Rao, Z.U. R., Iqbal, A., \& Tauni, M. Z. (2016). Performance persistence in institutional investment management: The case of Chinese equity funds. Borsa Istanbul Review, 16(3), 146-156. https://doi. org/10.1016/j.bir.2016.05.002

19. TCMA. (2020). Turkish Capital Markets Association ReportDecember 2020. Retrieved from https://www.tspb.org.tr/wpcontent/uploads/2020/12/Turkish_ Capital_Markets-202012-TR.pdf

20. Urbański, S., Winiarz, M., \& Urbański, K. (2016). Long-run performance persistence of investment funds. Emerging Markets Finance and Trade, 52(8), 18131831. https://doi.org/10.1080/1540 496X.2015.1069134

21. Wermers, R. (1997). Momentum investment strategies of mutual funds, performance persistence, and survivorship bias (Working Paper). University of Colorado. 